\title{
STUDI FENOMENOLOGI \\ PENGALAMAN KELUARGA SUKU BANJAR \\ SELAMA MERAWAT ANGGOTA KELUARGA DENGAN KONDISI STROKE DI BANJARMASIN
}

\author{
Oktovin $^{1}$, Nurachmah, Elly ${ }^{2}$, M.Syafwani ${ }^{3}$ \\ ${ }^{1}$ Mahasiswa Pascasarjana Ilmu Keperawatan Universitas Muhammadiyah Banjarmasin, 70114, \\ Indonesia \\ ${ }^{2}$ Staff Dosen Fakultas Keperawatan Universitas Indonesia, 16424, Indonesia \\ ${ }^{3}$ Staff Dosen Pascasarjana Universitas Muhammadiyah Banjarmasin, 70114, Indonesia
}

*Email:oktavin24@gmail.com

\begin{abstract}
ABSTRAK
Latar Belakang : Prognosis penyakit stroke kebanyakan sembuh dengan kecacatan. Kalimantan selatan terutama Kota Banjarmasin angka kejadian stroke mencapai 4.031 kasus yang sembuh dengan gejala sisa. Gejala sisa ini menjadikan penderita stroke di Kota Banjarmasin memiliki kualitas hidup rendah, terlebih lagi dengan rendahnya dukungan keluarga.

Metode : Metode penelitian dengan metode kualitatif fenomenology. Penelitian dilaksanakan dengan wawancara mendalam dan catatan lapangan (field note) kepada 5 partisipan yang terpilih sesuai kriteria inklusi. Data hasil wawancara dan catatan lapangan di analisa dengan tematik analisis.

Hasil : Penelitian ini menghasilkan 6 tema yaitu : kurangnya pengetahuan keluarga Suku Banjar tentang stroke; kebutuhan dasar pasien stroke tidak terpenuhi; keluarga memenuhi kebutuhan dasar pasien stroke; sikap keluarga selama merawat pasien stroke; sistem pemberian layanan kesehatan; dan pendekatan keluarga dalam asuhan keperawatan.

Kesimpulan : Keluarga Suku Banjar memiliki pengetahuan rendah tentang stroke. Hal ini berdampak pada koping keluarga sehingga di awal keluarga sempat menunjukan sikap tidak mendukung. Peran petugas kesehatan mengajarkan keluarga menjadi caregiver menjadikan keluarga saat ini mampu memaksimalkan perawatan kepada penderita stroke.
\end{abstract}

Kata Kunci : Keluarga Suku Banjar, Pasien Stroke, Perawatan Stroke 


\section{PENDAHULUAN}

Kebutuhan penderita stroke cukup beragam untuk dipenuhi, tetapi keluarga masih beranggapan bahwa perawatan stroke hanya berfokus pada masalah penyakitnya (Creasy, et al., 2016). Salah satu kebutuhan penderita stroke yang wajib terpenuhi yaitu kebutuhan dasar manusia, tetapi sebagian besar belum dipahami keluarga. Pemenuhan kebutuhan dasar manusia bertujuan mempertahankan kehidupan dan kesehatan (Hidayat \& Uliyah, 2014) dan perawatan diri menjadi salah satu yang harus terpenuhi, karena dampak ketidakmampuan memenuhi perawatan diri ini secara fisik menyebabkan masalah penyakit baru. Hambatan perawatan diri secara psikososial menyebabkan gangguan rasa nyaman, merasa tidak dicintai dan mencintai, gangguan harga diri, terhambatnya aktualisasi diri dan gangguan interaksi sosial (Tarwoto \& Wartonah, 2011).

Tingginya kejadian stroke di Indonesia hingga mencapai 10,9\%o permil tahun 2018 serta angka kejadian stroke di Provinsi Kalimantan Selatan menduduki peringkat 6 dari seluruh provinsi di Indonesia perlu menjadi perhatian (KEMENKES RI, 2018). Angka kejadian stroke di Kota Banjarmasin tahun 2018 mencapai 4.046 jiwa dan menjadikan stroke peringkat 3 dari 11 Penyakit Tidak Menular (PTM) menjadi masalah tersendiri yang perlu diselesaikan (DINKES Kota Banjarmasin, 2018). Masalah tersebut berkaitan dengan kecatatan yang menjadikan penderita kurang produktif setelah serangan stroke (Irfan, 2012) ditambah lagi dengan kurang berperannya keluarga dalam membantu penderita memenuhi kebutuhan dasarnya (Basit \& Rahmiyani, 2017).

Kurang berperannya keluarga dalam memenuhi kebutuhan dasar dapat dipengaruhi karena kurangnya pemahaman keluarga akan hal tersebut (Creasy, et al., 2016). Banyak hal yang mempengaruhi keluarga tidak memahami permasalahan stroke, misalnya kurangnya paparan informasi tentang gejala stroke (Rachmawati, dkk, 2017), tingkat pendidikan (Obembe, et al, 2014) dan metode perencanaan pulang dari petugas kesehatan belum terstruktur
(Yuniarsih, 2010). Kurangnya pemahaman tentang stroke tentu akan berdampak pada kemampuan keluarga dalam merawat penderita stroke.

Keluarga Suku Banjar di Kota Banjarmasin menjalankan perannya sebagai caregiver cenderung rendah (Basit \& Rahmiyani, 2017). Keluarga cenderung diam ketika melihat masalah ketidakmampuan pemenuhan kebutuhan perawatan diri penderita stroke selama di Rumah Sakit (Sari, Syuhaimi, \& Nurhikmah, 2018). Pengalaman peneliti sendiri menemukan beberapa keluarga tidak mempedulikan masalah pemenuhan kebutuhan harian penderita stroke selama dirawat di Rumah Sakit. Hasil studi pendahuluan 26 September 2019 di Poli Syaraf RSUD Ulin Banjarmasin kepada 2 partisipan yaitu anggota keluarga inti penderita stroke dan bersuku banjar terungkap keluarga awalnya tidak mengetahui tentang gejala stroke, sehingga keluarga cenderung merasa stres terhadap perubahan kemampuan penderita stroke setelah serangan. Keluarga juga awalnya merasa emosional, seperti rasa marah karena merasa terbebani. Rasa emosional tersebut sering dirasakan oleh anggota keluarga selama merawat penderita stroke.

Temuan di atas menjadi dasar bagi peneliti untuk mengeksplor "Pengalaman Keluarga Suku Banjar Dalam Memperoleh Informasi Tentang Stroke Sebagai Dasar Perawatan Pasien Stroke di Banjarmasin"

\section{METODE PENELITIAN}

Penelitian ini menggunakan pendekatan penelitian kualitatif dengan desain fenomenologi deskriptif atau transenden. Peneliti mencoba mengeksplorasi secara langsung, menganalisis dan mendeskripsikan fenomena yang diteliti melalui pengungkapan intuisi peneliti secara maksimal terhadap fenomena yang diteliti (Afiyanti \& Rachmawati, 2014).

Partisipan yang terlibat berjumlah 5 orang yang dipilih berdasarkan kriteria inklusi. Kriteria inklusi partisipan tersebut yaitu : 
1. Anggota keluarga dari penderita stroke (ibu, ayah, anak, istri/suami).

2. Anggota keluarga bersuku Banjar atau keturunan asli Suku Banjar dari kedua orang tua.

3. Tinggal satu rumah selama \pm 2 tahun dengan penderita stroke di daerah sekitar Kota Banjarmasin.

4. Setuju menjadi partisipan, mampu berkomunikasi dengan baik dan mampu menggunakan Bahasa Indonesia dan Bahasa Banjar.

Peneliti mengumpulkan data dari 5 partisipan dengan cara wawancara mendalam (indepth interview) dan field note. Wawancara dan field note dilaksanakan peneliti dengan bantuan alat perekam (recorder) dan buku catatan. Wawancara yang digunakan adalah wawancara semi berstruktur dengan menggunakan pertanyaan terbuka (open-ended question). Pertanyaan urutannya tidak selalu sama pada setiap partisipan bergantung pada proses wawancara dan jawaban tiap individu dari partisipan. Namun pedoman wawancara menjamin bahwa peneliti mengumpulkan jenis data sama dari para partisipan. Field note digunakan peneliti dalam mencatat suasana tempat dan respon partisipan saat wawancara berlangsung.

Analisis data penelitian adalah dengan tematik analisis. Proses analisis data yaitu dengan membuat transkrip verbatim sesuai dengan rekaman wawancara dan catatan lapangan pada setiap partisipan. Transkrip yang telah tersusun kemudian dianalisis dengan membuat koding pada setiap kata kunci dari ungkapan partisipan. Setiap kata kunci tersebut kemudian dianalisa kembali untuk membentuk kategori. Setiap kategori dianalisa kembali untuk membentuk sub tema yang kemudian dianalisa menjadi tema hasil penelitian.

\section{HASIL PENELITIAN}

Penelitian ini menghasilkan 6 tema penelitian, yaitu :

Kurangnya pengetahuan keluarga Suku Banjar tentang stroke. Tema ini terbentuk dari
2 sub tema yaitu keluarga tidak memahami tentang stroke dan cara keluarga memahami stroke. Keluarga tidak memahami stroke didasari oleh ungkapan 2 partisipan yang menyatakan awalnya tidak tahu tentang stroke, seperti kutipan berikut ini :

“dulu tu kada paham lalu ding ai”(P2)

"nah apa yo lah, kada tahu jua ulun”(P5)

Respon lain muncul yaitu keluarga tidak memahami stroke karena belum pernah mendapat penjelasan tentang stroke, seperti kutipan berikut ini:

"kada tahu ulun tentang stroke tu apa, kada suah dijelasi" (P4)

Cara keluarga memahami stroke adalah berdasarkan pengalaman pribadi. Pengalaman tersebut berupa pengalaman ketika melihat tanda dan gejala stroke dari anggota keluarga sendiri dan penderita stroke lain. Kutipan ungkapan tersebut yaitu:

"nang ulun tahu lah stroke tu, oleh ulun ni suah beisi keluarga kana stroke" (P3)

"mungkin stroke tu nang kaya mama ku ini kalo lah" (P5)

Kutipan ungkapan dari salah satu partisipan menyatakan memahami stroke karena melihat tanda gejala stroke penderita lain yaitu:

"mengawani mendata stroke di wilayah sini, jadi sedikit banyaknya aku kawa memahami...sekalinya setiap aku betamu lawan orang stroke, lain-lain bekelakuan” (P2)

Kebutuhan dasar pasien stroke tidak terpenuhi. Tema ini terbentuk dari 2 sub tema yaitu kebutuhan dasar biologis dan kebutuhan dasar psikologis. Gangguan pemenuhan kebutuhan dasar biologis misalnya seperti : gangguan pola eliminasi, gangguan menelan, kelemahan fisk, mati rasa, wajah asimetris, hambatan mobilitas fisik dan gelisah. Berikut ini beberapa kutipan partisipan :

"ngalih menahan kamih lawan

bahera...ngalih makan" (P1)

"pina uyuh pinanya" (P2) 
Respon lain yang muncul yaitu penderita stroke mengalami gangguan pemenuhan dasar psikologis. Keluarga mengungkapkan adanya hambatan pada komunikasi verbal dan satu partisipan merasa anggota keluarganya selalu bersikap emosional. Kutipan dari ungkapan partisipan tersebut yaitu :

"ni pang, nang ngalih bepander segala" (P2).

Keluarga memenuhi kebutuhan dasar pasien stroke. Tema ini terbentuk dari 4 sub tema yaitu pemenuhan kebutuhan dasar biologis, pemenuhan kebutuhan dasar spiritual, pemenuhan kebutuhan dasar psikologis dan merawat keluarga yang mengalami gangguan kesehatan. Pemenuhan kebutuhan dasar biologis diberikan keluarga seperti memenuhi kebutuhan makan dan minum. Kutipan ungkapan tersebut yaitu :

"mambari makan, kena ada jamnya"(P3)

"mambari makan aku ni ding ai... mambari akan minum jua aku ni ding ai”" (P5)

Respon lain yaitu keluarga membantu penderita stroke untuk beraktifitas, seperti kutipan berikut ini :

"kadang abahnya ni ngalih bediri, jadi dibantui bangun.... duduk akan dikursi roda nyaman sidin kawa ulun bawa kemana-mana" (P1).

Keluarga juga membantu anggota keluarganya dengan stroke untuk memenuhi kebutuhan tidur. Kutipan ungkapan tersebut yaitu :

"jadi sidin rancak ulun guring akan di tilam situ" (P1) ulun” (P4)

"mengguringkan akan sidin di ranjang ai

Keluarga juga memenuhi kebutuhan kebersihan diri penderita stroke. Kutipan ungkapan tersebut yaitu :

"Menyeka tiap pagi... popoknya hibak diganti akan” (P3)

"mandi akan sidin ni saban hari" (P5)
Respon lain muncul yaitu terkait bantuan pemenuhan kebutuhan spiritual penderita stroke oleh keluarga, seperti kutipan berikut ini :

"kena ku download akan lagu-lagu religi, nang kaya selawat, zikir.... ya jar ku, bah bawa bersabar bah lah, bawa be zikir aja bah ai" (P2).

Respon lainnya yaitu terkait pemenuhan kebutuhan psikologis. Keluarga mencoba memberi pengertian kepada penderita stroke ketika penderita tersebut dalam kondisi emosi. Kutipan ungkapan tersebut yaitu :

"membisai sidin, amun sidin lagi mehamuk" (P4)

Keluarga tidak ingin membebankan penderita dengan beban pekerjaan maupun beban pikiran. Kutipan dari ungkapan tersebut yaitu :

"kena kami membahagiakan sidin... karena kan jar orang stroke tu jangan dibebani kayatu.... sekira jangan menjadi beban gasan yang garing" (P2)

Respon lainnya yaitu terkait berjalannya peran keluarga dalam merawat anggota keluarga yang mengalami masalah kesehatan. keluarga merawat dengan membantu mengontrol dan mengobati penyakit. Kutipan dari ungkapan tersebut yaitu:

"meantar bapak terapi karena bapak disuruh terapi” (P1)

"ada jamnya minum obat, diminumi.... bila inya sakit banar kepala ditensi.... bila tensi tinggi langsung diminumi obat" (P3)

Sikap keluarga dalam merawat pasien stroke. Tema ini terbebntuk dari 2 sub tema yaitu sikap mendukung dan sikap tidak mendukung. Sikap mendukung ditunjukan keluarga dengan tindakan nyata. Tindakan tersebut yaitu keluarga mau menerima tanggung jawab untuk merawat dan mendengarkan dengan baik ungkapan penderita stroke walaupun ada keterbatasan penyampaian. Kutipan ungkapan tersebut yaitu :

"itu ja nang tepikir sampai aku dak bebulik” (P1) 
“mandangari bebujur tu pang” (P1)

Sikap mendukung lainnya ditunjukan keluarga dalam bentuk perasaan yaitu munculnya rasa kasihan, seperti kutipan berikut ini :

"kasihan lawan bapak tu kenapa jadi kaya itu.... maras aku melihat" (P2)

Sub tema lainnya yang membentuk tema ini yaitu sikap tidak mendukung dari keluarga. Keluarga menunjukan sikap ini dalam bentuk tindakan nyata yaitu pernah meninggalkan penderita stroke dan keluarga bahkan terpaksa dalam melakukan kegiatan perawatan. Kutipan ungkapan tersebut yaitu :

\section{"paksa ai aku begawian jua" (P1)}

"pas abahnya tu garing suah $k u$ tinggal akan bulik kekampung... tepikir bahkan terlaksana niat ku meninggalkan keluarga” (P1)

Sikap tidka mendukung dari keluarga juga ditunjukan dalam bentuk perasaan yaitu pernah merasa menyerah dan tidak tahan atas perubahan kondisi kehidupan. Kutipan ungkapan tersebut yaitu :

"saking kada tahannya tadi tu” (P1)

"sadang aku aja rasa dak manyarah ding $a i ”(\mathrm{P} 2)$

\section{Sistem pemberian layanan kesehatan.} Tema ini terbentuk dari 2 sub tema yaitu perawatan langsung dan perawatan tidak langsung. Perawatan langsung yang dirasakan oleh keluarga sebagai bentuk nyata dari berjalannya system pemberian layanan kesehatan salah satunya yaitu pendidikan kesehatan. Kutipan ungkapan tersebut yaitu:

"palingan dipanderi, dipadahi buhannya bahwa penyakit stroke ni kada capat ampihnya...Perlu waktu jar sidin dirawat disini. Bisa sampai setengah bulan hanyar bujur-bujur kawa dibawa bulik" (P3).

Layanan kesehatan langsung lainnya yang terungkap dalam penelitian ini yaitu aktifnya tim kesehatan memperhatikan masalah kesehatan di masyarakat, seperti kutipan berikut ini: "puskesmas datangan kena... setiap bulan kepuskesmas mengontrol kesehatan, pasti diberi obat gratis" (P1)

"kalo pina ada gejala biasanya disuruh kepuskesmas supaya dapat obat" (P4)

Respon lain terkait tema ini adalah layanan kesehatan tidak langsung. Keluarga merasa jaminan kesehatan merupakan salah bentuk layanan kesehatan yang secara tidak langsung membantu keluarga dan penderita stroke. Seperti kutipan ungkapan berikut:

"untung lah ding lah, dapat nang itu ding ai, dapat BPJS dari pemerintah, jadi kada bayar kada apa-apa jua jaer ku bah ae" (P2).

\section{Pendekatan keluarga dalam asuhan keperawatan.}

Tema ini terbentuk dari 2 sub tema yaitu kebutuhan psikososial penderita dan strategi mempersiapkan keluarga menjadi caregiver. Keluarga diharapkan terlibat dalam perawatan agar memenuhi kebutuhan psikososial penderita. Cara keluarga terlibat dalam asuhan keperawatan adalah dengan selalu berada disamping penderita. Tujuan dari tindakan ini untuk mempermudah penderita saat ingin meminta bantuan dan merasa dipedulikan. Keluarga juga diminta untuk mengajak penderita berkomunikasi. Kutipan ungkapan tersebut yaitu:

"kami disuruh perawat supaya keluarga biar labih rakat jarnya kayatu bu ai...keluarga itu harusnya selalu disamping pasien jarnya" (P3)

"ya jar perawat bawai pander sidin nih nyaman bahagia jua sidinnya pas dulu tuh" (P5)

Keluarga juga terlibat dalam asuhan perawatan sebagai strategi mempersiapkan keluarga menjadi caregiver. Petugas kesehatan melatih keluarga melakukan perawatan. Kutipan ungkapan tersebut yaitu:

"harus kawa tu pang, kena ngalih dirumah jar...dirumah kena dimandi akan rutin, dimakani rutin nang kaya kami ajari jar caranya" (P5) 


\section{PEMBAHASAN}

\section{Kurangnya pengetahuan keluarga Suku} Banjar tentang stroke.

Keluarga Suku Banjar tidak memahami tentang stroke sebelumnya karena keluarga belum mendapatkan informasi tersebut. Keluarga hanya mendapatkan informasi tentang diagnosa penyakit. Temuan inilah yang menjadi gambaran rendahnya pengetahuan keluarga Suku Banjar tentang stroke.

Temuan tersebut sama dengan hasil penelitian Maclsaac, et al (2011), dimana Sekitar $50 \%$ caregiver belum mendapatkan informasi yang diinginkan seperti pemahaman tentang pencegahan dan penanganan stroke serta akses untuk mendapatkan informasi yang mendukung pasien dan keluarga. Padahal informasi, edukasi dan perencanaan pulang terkait masalah dan pemenuhan kebutuhan fisik dan psikologis penderita stroke sangat diperlukan oleh keluarga selaku caregiver terutama untuk memenuhi kebutuhan dasar pasien stroke tahap paska akut (Yuniarsih, 2010).

Hal yang sedikit berbeda dengan temuan Mant.J., et al (2000), dimana pengetahuan keluarga sebagai caregiver memang rendah, akan tetapi tidak menunjukan perbedaan yang signifikan setelah diberi informasi. Banyak sekali hal yang mempengaruhi seseorang memahami stroke. Tingkat pendidikan, tingkat penghasilan dan usia menjadi salah satu faktor. Rendahnya kesadaran masyarakat daerah terpencil juga menjadi salah satu faktor yang mempengaruhi pengetahuan karena kurangnya paparan informasi dibanding masyarakat wilayah perkotaan (Hokmabadi, Vahdati, Rikhtegar, Ghasempor, \& Rezabakhsh, 2019)

Kurangnya pengetahuan keluarga Suku Banjar tentang stroke pada penelitian ini berkaitan dengan tingkat pendidikan partisipan. Tingkat pendidikan keluarga Suku Banjar yang menjadi partisipan hanya lulusan Sekolah Dasar (SD) sampai dengan Sekolah Menengah Atas (SMA). Keluarga Suku Banjar menurut Haryanto (2012) memiliki pengaruh yang rendah kepada anggota keluarga terutama anak untuk melanjutkan pendidikan. Keluarga Suku Banjar tidak melarang terutama bagi anak-anaknya untuk bekerja atau menikah di usia belia.
Padahal pendidikan merupakan faktor internal yang mempengaruhi pengetahuan seseorang (Notoadmodjo, 2007). Semakin tinggi tingkat pendidikan semakin tinggi pula kesadaran keluarga untuk mencari informasi (Ratnawardani, dkk., 2018).

Rendahnya tingkat pendidikan keluarga Suku Banjar berbanding terbalik dengan nilai budaya Banjar. Parhani (2016) menjelaskan bahwa suku Banjar dikenal sebagai suku yang memiliki nilai "Kompetitif Individual" atau sebagai orang yang bekerja keras dalam mencapai cita-cita. Temuan ini menjadi gambaran bahwa terjadi penurunan nilai Budaya pada masyarakat Banjar.

Beberapa hal yang dipahami oleh keluarga Suku Banjar tentang stroke yaitu penderita stroke mengalami keterbatasan kemampuan dari biasanya. Pemahaman ini muncul berdasarkan pengalaman keluarga melihat tanda dan gejala stroke dari anggota keluarganya. Temuan ini diperkuat oleh Wawan \& Dewi (2010) yang mengungkapkan pengalaman terdahulu dapat membentuk pengetahuan seseorang. Banyak keluarga memahami stroke berdasarkan tanda dan gejala yang terlihat dari penderita. Pengalaman melihat tanda gejala penderita sangat baik dalam upaya pengenalan masalah sehingga mempengaruhi urgensi penanganan stroke (Ratnawardani, dkk., 2018).

Keluarga Suku Banjar memahami bahwa tanda dan gejala stroke setiap penderita berbeda. Sama halnya dengan temuan Lopez-Espuela, et al (2018), keluarga terutama pasangan memahami adanya perbedaan tanda gejala stroke dari segi fisik, kognitif, emosional, perilaku atau temperamental antara pasangannya dengan stroke dan penderita lain. Perbedaan tanda dan gejala stroke pada setiap penderita tergantung letak kerusakan otak yang terjadi (Ariani, 2012).

Temuan dimana keluarga Suku Banjar memahami bahwa tanda dan gejala stroke setiap penderita berbeda salah satunya dipengaruhi oleh lingkungan pekerjaan. Bekerja di salah satu fasilitas kesehatan tentu akan menjadikan seseorang memiliki banyak pengalaman dalam melihat kondisi seseorang yang sakit dengan berbagai macam penyakit. Temuan ini dibenarkan oleh Notoadmodjo (2007), dimana 
pekerjaan merupakan salah satu faktor internal individu untuk memperoleh pengetahuan. Pengetahuan ini terbentuk dari kerja pancaindera, terutama 2 pancaindera yaitu penglihatan dan pendengaran dalam membentuk pengetahuan.

\section{Kebutuhan dasar pasien stroke tidak terpenuhi.}

Keluarga Suku Banjar menyadari penderita stroke mengalami gangguan kebutuhan dasar biologis dan psikologis seperti gangguan buang air kecil (BAK) dan buang air besar (BAB), gangguan menelan, mati rasa, wajah tampak asimetris, hambatan mobilitas fisik dan terganggunya kemampuan komunikasi secara verbal serta gangguan emosional.

Creasy, et al (2016) mengungkapkan bahwa stroke secara umum dapat mempengaruhi kebutuhan biologis, hubungan sosial dan psikologis penderitanya. Penderita stroke dapat sembuh tetapi meninggalkan gejala sisa seperti gangguan berjalan, gangguan bicara, gangguan buang air kecil, gangguan emosi, gangguan berpikir dan lain-lain (Handayani \& Dewi., 2009). Perubahan mental, emosi dan depresi cenderung terjadi pada penderita stroke (Lingga., 2013). Penderita stroke dengan kondisi vegetative state bahkan mengalami perubahan signifikan dari segi kognitif dan perilaku (Arafat., 2010). Faktor penyebabnya adalah kerusakan neurovaskuler akibat stroke (Ariani., 2012).

Temuan ini juga menunjukan keluarga dengan Suku Banjar mampu menjalankan perannya dengan baik yaitu mengenali masalah kesehatan setiap anggota keluarganya (Friedman., 2010). Kemampuan mengenali masalah kesehatan pada setiap anggota keluarga menjadi salah satu sumber pengetahuan yang akan mempengaruhi sikap seseorang (A.Wawan \& Dewi., 2010). Terutama sikap yang mendukung pemulihan stroke.

\section{Keluarga memenuhi kebutuhan dasar pasien stroke.}

Keluarga Suku Banjar berusaha memenuhi kebutuhan dasar penderita stroke. Kebutuhan dasar yang dipenuhi yaitu kebutuhan dasar biologis, psikologis, spiritual dan upaya merawat keluarga yang mengalami gangguan kesehatan. Kadarwati, dkk (2019) menjelaskan bahwa keluarga berupaya memenuhi hampir semua kebutuhan penderita pasca stroke karena defisit fungsional yang dialami penderita stroke meliputi pemenuhan kebutuhan nutrisi, cairan, kebersihan diri, berpakaian dan berhias, mobilisasi, spiritual dan sosial. Penderita stroke sangat bergantung pada caregiver dalam pemenuhan aktifitas perawatan diri dan mobilitas karena adanya gangguan atau defisit neurologis (Hesamzadeh, et al., 2016).

Keluarga Suku Banjar berusaha memenuhi kebutuhan spiritual dalam upaya mengendalikan kebutuhan psikologis penderita stroke. Keluarga menginginkan penderita stroke menerima dan mampu mengendalikan perilaku emosional secara mandiri, yaitu dengan berdzikir dan berdoa. Widarti \& Krisnawati (2012) mengungkapkan bahwa berdzikir dan berdoa akan menciptakan perasaan damai, tenang dan suasana emosi diliputi oleh emosi-emosi positif. Berdzikir dengan penuh konsentrasi akan memunculkan gelombang alpha dan menimbulkan perubahan kesadaran seseorang, dari kesadaran normal menuju kesadaran lain yang sering disebut sebagai altered states of consciousness (ASC).

Temuan ini didukung oleh Dewi, dkk (2017) yang menjelaskan depresi pada penderita stroke akan mempengaruhi emosional penderita. Dukungan spiritual dari keluarga ternyata berdampak positif untuk menurunkan perilaku emosional penderita.

Agianto \& Setiawan (2017) menjelaskan bahwa kualitas hidup penderita stroke dapat terbantu dengan aktifnya keluarga sebagai caregiver. Suppoert system yang baik dan positif dari keluarga akan membantu proses pemulihan penyakit stroke (Maria, 2014), karena keluarga memiliki tanggung jawab dalam merawat anggota keluarga dengan stroke atas dasar kepedulian (Moral-Fernadez, et al., 2018) dan mampu memberikan rasa nyaman, rasa percaya, empati dan perhatian atas dasar ikatan (Dewi \& Darliana, 2017). 


\section{Sikap keluarga dalam merawat pasien stroke.}

Keluarga dengan Suku Banjar menunjukan sikap yang mendukung dan tidak mendukung selama merawat penderita stroke. Sikap mendukung ataupun yang tidak mendukung ditunjukan dalam bentuk tindakan nyata atau perilaku, persepsi atau pandangan dan juga perasaan. Temuan ini didukung oleh Baron., et al dalam Wawan \& Dewi (2010) yang mengungkapkan 3 komponen sikap yaitu kognitif (perseptual), afektif (emosional) dan konatif (perilaku).

Sikap mendukung dari keluarga Suku Banjar selama merawat penderita stroke adalah seperti memberi perawatan secara langsung atas dasar tanggung jawab terhadap perannya di keluarga, menjadi pendengar yang baik dalam upaya mengendalikan emosional penderita stroke dan rutin mengontrol kesehatan penderita. Temuan ini diperkuat Kadarwati, dkk (2019) dimana keluarga menjadi caregiver bagi penderita stroke karena bertanggungjawab dalam menjalankan fungsinya dalam keluarga. Salah satu fungsi tersebut yaitu memberikan perawatan pada anggota keluarga yang sakit (Friedman, 2010). Widarti \& Krisnawati (2012) juga menjelaskan komunikasi verbal dan non verbal, bantuan nyata atau tindakan yang diberikan oleh keakraban sosial atau berupa kehadiran dan mempunyai manfaat emosional atau berpengaruh pada perilaku penerimanya.

Sikap tidak mendukung keluarga Suku Banjar juga ditunjukan saat awal keluarga menghadapi perubahan kondisi anggota keluarganya dengan stroke. Sikap tersebut seperti pergi meninggalkan keluarga dan mengeluh tidak tahan dengan perubahan kondisi tersebut. Sikap tidak mendukung ini menggambarkan keluarga harus menghadapi perubahan kondisi akibat stroke yang sebenarnya merupakan beban dan berdampak negatif bagi keluarga.

Tooth, et al (2005) di dalam Luthfa (2018) menjelaskan 12 bulan pertama family caregiver mengalami kecemasan dan depresi terkait pelaksanaan tugas (misalnya memberi bantuan fisik) dan lamanya waktu perawatan yang ratarata 5-9 jam per hari. Adaptasi terhadap perubahan kondisi kehidupan setelah anggota keluarga menderita stroke merupakan suatu tantangan yang cukup berat. Keluarga harus mampu membantu penderita stroke bahkan keluarga merasa stroke memiliki dampak negatif bagi kehidupan keluarga (Tilling, Coshall, McKevitt, Daneski, \& Charles, 2006). Dampak negatif tersebut seperti beban berlebih dari adanya tuntutan ekonomi dan waktu singkat dalam perawatan, ketergantungan penderita stroke dengan keluarga, kesabaran yang tinggi dalam menghadapi emosi penderita stroke, dan menurunnya produktivitas dalam keluarga (Masitoh, Asiyah \& Sholihah, 2014).

\section{Sistem pemberian pelayanan kesehatan}

Pemerintah melalui program kesehatan menyediakan layanan kesehatan bagi penderita stroke dan keluarga. Bentuk layanan kesehatan tersebut seperti layanan kesehatan langsung dan tidak langsung. Layanan kesehatan langsung berupa pengontrolan dan pengobatan penyakit serta pendidikan kesehatan.

Layanan kesehatan dapat ditemui di rumah sakit, puskesmas, klinik dokter, perawat dan bidan (Yuliana, 2013). Pos Pembinaan Terpadu Pengendalian Penyakit Tidak Menular (Posbindu-PTM) salah satu contoh layanan untuk menangani penyakit tidak menular (RI, 2016). Fasilitas ini digunakan dalam upaya pengobatan dan pencegahan untuk menurunkan resiko yang diakibatkan dari suatu penyakit (Ratnawardani, Utomo, \& Safri, 2018) dengan kegiatan salah satunya pendidikan kesehatan. Keluarga membutuhkan informasi tentang faktor-faktor mempengaruhi pemulihan penyakit stroke (Agianto \& Setiawan., 2017) karena sebagian besar keluarga adalah orang awan yang baru pertama kali merawat penderita stroke dirumah (Kadarwati, Ulfa.R, \& Oktarina.E, 2019).

Layanan kesehatan tidak langsung juga dirasakan oleh keluarga seperti bantuan jaminan kesehatan dari pemerintah. Jaminan kesehatan ini mengurangi beban biaya kesehatan. Tseng,et al (2005) menguraikan bantuan dana kesehatan sangat dibutuhkan keluarga. Bantuan dana tersebut untuk memfasilitasi keluarga merawat 
anggota keluarganya dengan stroke (Agianto \& Herry., 2017).

Temuan ini ternyata bertolak belakang dengan Kartika, dkk (2015) dimana banyak keluarga merasakan belum mendapatkan perhatian dari tim palayanan kesehatan sehingga berdampak pada pengetahuan dan kemampuan keluarga dalam memberikan perawatan.

\section{Pendekatan keluarga dalam asuhan keperawatan}

Stroke memerlukan waktu panjang untuk proses penyembuhan. Keluarga diharapkan dapat menjadi caregiver utama bagi penderita stroke terutama ketika kembali kerumah. Tidak heran jika banyak tenaga kesehatan berupaya menjadikan keluarga sebagai caregiver dengan sklill terlatih.

Orem
beberapa kasus pasien ketergantungan keperawatan yang lama. Tenaga perawat diharapkan mampu menjadikan keluarga atau teman dari pasien untuk menjadi agen perawatan diri dalam membantu penderita ketergantungan keperawatan (Alligood, 2017). Handayani \& Dewi (2009) juga menjelaskan keterlibatan keluarga memang sangat diperlukan oleh penderita stroke terutama dalam membantu penderita karena keterbatasannya.

\section{KESIMPULAN}

Keluarga Suku Banjar tidak memiliki pengetahuan cukup tentang stroke. Dampaknya keluarga belum terfasilitasi untuk membentuk koping sejak dini. Koping yang tidak efektif ini cenderung menjadikan keluarga mampu menunjukan sikap tidak mendukung yang terlihat selama ini. Upaya membentuk koping keluarga tentu dapat dibentuk melalui peran dari petugas kesehatan selama memberikan layanan misalnya melalui pendidikan kesehatan dan pengajaran atau pelatihan menjadi caregiver, sehingga keluarga mampu memenuhi kebutuhan dasar penderita stroke secara maksimal.

\section{DAFTAR PUSTAKA}

Afiyanti, D., \& Rachmawati, I. (2014). Metodologi Penelitian Kualitatif dalam Riset Keperawatan. Jakarta: Rajawali Pers.

Agianto, \& Setiawan, H. (2017, September). Supportive Care Needs Pada Keluarga Pasien Stroke di Klinik Syaraf Banjarmasin, Indonesia. Dunia Keperawatan, 5, 107-114.

Alligood, M. R. (2017). Pakar Teori Keperawatan dan Karya Mereka (Vol. 1). (A. Hamid, \& K. Ibrahim, Eds.) Singapore: ELSEIVER.

Arafat, R. (2010). Pengalaman Pendampingan Keluarga Dalam Merawat Anggota Keluarganya Pada Kondisi Vegetative Dalam Konteks Asuhan Keperawatan di RSUP. Fatmawati Jakarta. Tesis. Depok : Universitas Indonesia.

Ariani, T. A. (2012). Sistem Neurobehaviour. Jakarta: Salemba Medika.

Basit, M., \& Rahmayani, D. (2017, Desember). The Quality Of Life Of Post-Stroke Patients At The Nerve Clinic Of Ulin General Hospital In Banjarmasin. Advanced in Health Science Research, 6, 667-674. doi:https://doi.org/10.2991/smichs17.2017.83

Creasy, K., Lutz, B., Young, M., \& Stacciarini, J. (2016, November). Clinical Implications of Family-Centered Care Ind Stroke Rehabilitation. HHS Public Access, 1-14.

Dewi, C., \& Darliana, V. (2017). Dukungan Keluarga dengan Depresi pada Pasien Pasca Stroke. Idea Nursing Journal, VIII, 1-7.

DINKES Kota Banjarmasin. (2018). Jumlah kasus dan kematian penyakit tidak menular berdasarkan jenis kelamin dan umur di Kota Banjarmasin. Banjarmasin : Dinas Kesehatan Kota Banjarmasin

Friedman, M. (2010). Keperawatan Keluarga : Teori dan Praktek. Jakarta: EGC.

Handayani, D., \& Dewi, D. (2009, Februari). Analisis Kualitas Hidup Penderita dan Keluarga Pasca Serangan Stroke (Dengan Gejala Sisa). PSYCHO IDEA, 35-44.

Hesamzadeh, A., Dalvandi, A., Bagher Maddah, S., Fallahi Khoshknab, M., Ahmadi, F., \& Arfa, 
M. (2016). Family caregivers' experience of activities of daily living handling in older adult with stroke : a qualitative research in the Iranian Context. Scandinavian Journal of Caring Sciences, 1-12.

Hidayat, A. A., \& Uliyah, M. (2014). Pengantar Kebutuhan Dasar Manusia. Jakarta: Salemba Medika.

Hokmabadi, E., Vahdati, S., Rikhtegar, R., Ghasempor, K., \& Rezabakhsh, A. (2019). Public Knowledge of people visiting Imam Reza Hospital regarding stroke symptoms and risk factors. BMC Emergency Medicine, $1-5$.

Irfan, M. (2012). Fisioteraapi Bagi Insan Stroke. Yogyakarta: Graha Ilmu.

Kadarwati, Ulfa.R, \& Oktarina.E. (2019). Studi Fenomenologi : Pengalaman Keluarga Merawat Penderita Pasca Stroke di Kota Jambi Tahun 2019. Jurnal Ilmiah Universitas Batanghari Jambi, 476-480.

KEMENKES RI. (2018). Riset Kesehatan Dasar (RISKESDAS) Tahun 2018. Jakarta : KEMENKES RI.

Lingga, L. (2013). All about stroke hidup sebelum dan pasca stroke. Jakarta: Alex Media Komputindo.

Lopez-Espuela, F., Gonzalez-Zill, T., AmarillaDonoso, J., Cordovilla-Guardia, S., PortillaCuenca, J., \& Casodo-Naranjo, I. (2018). Critical Point in the Experience of Spouse Caregivers of Patients Who Have Suffered a Stroke. A Phenomenological Interpretative Study. PLOS ONE, 1-16.

Luthfa, I. (2018). Peran Keluarga Merawat Lansia Pasca Stroke (Family Role to Care Post Stroke Elderly). UNISSULA PRESS, 62-69.

Maclsaac, L., Harrison, M., Buchanan, D., \& Hopman, W. (2011). Supportive Care Needs After an Acute Stroke : A Descriptive Enquiry of Caregivers Perspective. Journal Of Neuroscience Nursing, 132-140.

Mant, J., Carter, J., Wade, D., \& Winner, S. (2000). Family Support for Stroke : a Randomised Controlled Trial. THE LANCHT, 808-813.

Maria, I. (2014, Juni). Support System Keluarga Tentang Range of Motion pada Pasien
Stroke. Jurnal Ilmu Kesehatan Insan Sehat, 2, 75-82.

Moral-Fernandez, L., Frias-Osuna, A., MorenoCamara, S., Palamino-Moral, P., \& Del-PinoCasado, R. (2018). The Start Of Caring For An Elderly Dependdent Family Member : a Qualitative Metasynthesis. BMC Geriatrics, 1-5. Retrieved from https://www.ncbi.nlm.nih.gov/pmc/articles/P MC6157059/pdf/12877_2018_Article_922.p df

Obembe, A., Alaogun, M., Bamikole, A., Komolafe, M., \& Odetunde, M. (2014). Awarness of Risk Factors and Warning Signs of Stroke in A Nigeria University. Jornal of Stroke and Cerebrospsinal Diseases, 749-758.

Parhani, I. (2016, Januari-Juni). Perubahan Nilai Budaya Orang Banjar (Dalam Perspektif Teori Troompenaar). AL-BANJARI, 15, 2756.

Rachmawati, D., Andarini, S., \& Kartikawati, D. (2017). Pengetahuan Keluarga Berperan Terhadap Keterlambatan Kedatangan Pasien Stroke Iskemik Akut di Instalasi Gawat Darurat. Jurnal Kedokteran Brawijaya, 368375.

Ratnawardani, D., Utomo, W., \& Safri. (2018). Pengalaman Keluarga dalam Penanganan Serangan Pertama Pada Pasien Stroke. JOM FKp , 259-267.

RI, K. K. (2016). Pedoman Umum : Program Indonesia Sehat dengan Pendekatan Keluarga. jakarta: KEMENKES RI.

Sari, R., Syuhaimi, P. Y., \& Nurhikmah. (2018). Studi Fenomenologi : Pengalaman Perawat Memenuhi Kebutuhan Personal Hygene Klien Dengan Keterbatasan Gerak Fisik. Tesis. Retrieved from http://eprints.umbjm.ac.id/id/eprint/290

Tarwoto, \& Wartonah. (2011). Kebutuhan Dasar Manusia dan Proses Keperawatan. Jakarta: Salemba Medika.

Tilling, K., Coshall, C., McKevitt, C., Daneski, K., \& Charles, W. (2006). A Family Support Organiser for Stroke Patients and Their Carers: A Randomised Controlled Trial. Cerebrovaskular Disease, 85-91. 
Tseng, C., Huang, G., Yu, P., \& Lou, M.-f. ( 2015). A qualitative study of family caregiver experiences of managing incontinence in stroke survivors. Plos One, 1-15.

Wawan, \& Dewi. (2010). Pengetahuan, sikap dan perilaku manusia. Yoyakarta: Nuha Medika.

Widarti, L., \& Krisnawati. (2012). HOME CARE HOLISTIC TERHADAP PERUBAHAN KECEMASAN DAN DEPRESI PADA PASIEN STROKE ISKEMIK (Home Care Holistic on the Change of Anxiety and Depression for the Patient with Stroke Ischemic). Jurnal Ners, 107-115.
Yuliana, P. D. (2013). Hubungan karakteristik keluarga dan jenis penyakit terhadap pemanfaatan pelayanan kesehatan. Pekanbaru: Program Studi Ilmu Keperawatan Universitas Riau .

Yuniarsih, W. (2010). Pengalaman Caregiver Keluarga dalam Konteks Asuhan Keperawatan Pasien Stroke Tahap Paska Akut di RSUP Fatmawati. FKIK Universitas Indonesia. 